\title{
DOCUMENTARY FRAUD AS SEEN BY THE DOCUMENTARY FRAUD BUREAU OF THE DIRECTION OF BORDER POLICE (Part I) \\ F. Mateaş
}

\author{
Florian Mateaş \\ Law and Economics Faculty, Social Sciences Department \\ Agora University of Oradea, Oradea, Romania \\ *Correspondence: Florian Mateaş, Agora University of Oradea, 8 Piaţa Tineretului St., Oradea, \\ Romania \\ E- mail: departament@univagora.ro
}

\begin{abstract}
Today, we are witnessing a globalisation and intensification which is unprecedented in the history of migratory flows in our country. These flows are now of a very complex nature as placed under criminal rule.

With this level of organisation, we are not just trying to counter illegal immigration, but fighting against criminality. In this respect, the use of forged documents or documentary fraud in general is a great boon to the activities of the clandestine networks and constitutes an excellent means of introducing illegal immigrants into Western countries.
\end{abstract}

\section{Keywords: migratory flows, documentary fraud, illegal immigration pathways}

\section{Introduction}

With respect to immigration or migratory flows, it may be useful to recall that Europe faced a considerable challenge.

Many factors lead us to think that there will be an increase in migratory pressure in the coming years and, in particular, an increase in demographic variations between now and the year 2050 , according to the populations division of the UN, together with the further widening of inequalities in richness and development.

However, even if Europe needs such a migratory inflow, it goes without saying that it must ensure it is controlled and must provide itself with a balanced policy with respect to asylum and immigration.

However, this aim runs up against the reality of a significant degree of illegal immigration. It is quite rightly necessary to insist on the significance of organised networks serving illegal immigration.

Indeed, it must be acknowledged that it is not by inspection that numbers of illegals increase, but on the contrary they arise through increasing activity by these smuggling networks and their organisation which is becoming ever more structured and equipped with substantial means which provide significant support to the entry of illegal aliens.

Today, we are witnessing a globalisation and intensification which is unprecedented in the history of migratory flows in our country. These flows are now of a very complex nature as placed under criminal rule.

Since 2009, migratory pressure for illegals towards the United Kingdom has grown exponentially and France is used as a transit country. Globalisation can be measured by the thousands of miles travelled by aliens who journey to countries in which they often have no cultural, linguistic or historical ties.

With this level of organisation, we are not just trying to counter illegal immigration, but fighting against criminality. In this respect, the use of forged documents or documentary fraud in general is a great boon to the activities of the clandestine networks and constitutes an excellent means of introducing illegal immigrants into Western countries. 
Thus, the transposition of Mafioso methods to the management of illegal migratory flows poses some substantial problems for the implementation of a relevant response, and means that it is necessary for there to be developments in the state departments which are responsible for providing this response, and the means that are made available to them. This is an activity giving rise to criminal $^{1}$ conduct (kidnapping, extortion, even imprisonment, etc.) which is practised with considerable logistical and technical resources.

\section{The phenomenon of documentary fraud}

It is not really possible to fully consider the phenomenon of documentary fraud without referring to the context in which it arises, that of migratory flows, and the nature of the pressure on our borders.

\section{Migratory flows.}

1.1. The organised trafficking of the population.

Considering that it was necessary, in order to fight illegal immigration networks, to have qualified investigators with national jurisdiction within a single department, the D.C.P.A.F. chose to create, in 2006, the office central pour la répression de l'immigration irrégulière et de l'emploi des étrangers sans titre (Central office against illegal immigration and illegal employment of aliens - acronym O.C.R.I.E.S.T.).

As the only central office which does not form part of the criminal investigation police, this department plays the part of privileged correspondent for the Brigades mobiles de recherche interrégionales (Inter-regional research mobile brigade) (B.M.R.I).

As international clandestine networks have little concern for borders, and put them to their own use, this means it is necessary for reinforced capacities of adaptation which must be shared by the police forces of the various States which are crossed ("source" State, "rebound or target" State).

Mastering control of migratory flows is a priority of the French Government. As a phenomenon which is by very nature international, it requires constant support and a willingness to act on the part of all of the administrative authorities and representatives of France.

- Updated description of illegal immigration networks and the newly identified networks.

Illegal immigration networks are international and in general highly structured. They defy the organisation of our traditional police forces, all the more easily as the risks run are completely out of step with the profits obtained from them. This criminal activity is undoubtedly one of the most lucrative today. It is now in the hands of true mafias. To this activity they add, in addition to the illegal labour of aliens without work permits, other offences such as prostitution, drug smuggling and money laundering.

Immigration is undertaken by the nationals of many countries. This summary, far from being exhaustive, only considers the most worrying flows connected to networks which are very efficient since they are highly structured.

It is based, within the D.C.P.A.F., by the work of the office central pour la répression de l'immigration irrégulière et de l'emploi des étrangers sans titre (Central office against illegal immigration and illegal employment of aliens - O.C.R.I.E.S.T.), as relayed locally by 44 research mobile brigades (B.M.R.s).

\footnotetext{
${ }^{1}$ Ion Suceava, Florian Coman, Crime and international organizations, ROMCARTEXIM Publishing, Bucharest, 2007 , p. 7.
} 


\section{F. Mateaş}

\subsection{The Chinese networks}

Chinese-origin immigration arises essentially from three southern provinces (Zhejiang, Fujian and Guangdong) with the destination of the European Union (particularly France), the U.S.A. and Australia.

It is particularly worrying for the French authorities for various reasons:

$>$ it is potentially the most dangerous;

$>$ it is always orchestrated by mafia-like networks, connected to the Triads;

$>$ it is difficult to penetrate, with substantial barriers in language and culture;

$>$ it is violent: the networks use a heavy hand when dealing with candidates for immigration (score-settling between networks and kidnapping of illegals, and the elimination of recalcitrant illegals).

The modus operandi

Many different transit routes have been discovered, covering air, land and sea travel.

By air, the illegals bearing suitable documents attempt direct arrival from Bangkok, sometimes indirectly arriving in the destination country by arriving in a country which is a member of the Schengen area, so as not to draw attention to themselves.

The routes have become more complicated in order to escape excessive border controls. For example, to arrive in Paris from Hong Kong, the networks will obtain a Hong Kong - Paris ticket from a European airport. Transit in these international airports means that the illegal can avoid police controls, and once arrived in Paris, controls are lighter as from a country in the Schengen area.

In general, Chinese illegals wishing to migrate to the West will arrive by plane in an Eastern European country (Czech Republic, Russia) then continue their voyage by land towards countries of the European Union, the United Kingdom in particular.

Since the beginning of 2012, there has been a particular desire amongst Chinese illegals to head for the United States ${ }^{2}$. For that, the networks have the illegals transit through a country in the Schengen area (especially France), and Mexico, to arrive in California over land. Recently, due to intensive American controls along the Californian border, a new route has been put into place to reach the American coast via certain Caribbean islands (the Bahamas, Cuba, and SaintMartin).

Moreover, over the last few years the African continent has become a springboard towards the Schengen area for the Chinese networks.

Since the beginning of the year, up to 20 July 2013, border police in the airport Paris Roissy Charles de Gaulle have proceeded with 421 procedures for non-admission for Chinese nationals using, for the majority, forged Korean and Japanese documents. They make use of their transit in France in order to enter the territory. They generally had smugglers waiting for them.

By land, the most commonly-followed route is the one which leads illegals into an Eastern European country (Poland, Russia, or Ukraine) transiting the Czech Republic, then crossing the "green border" between the Czech Republic and Germany. Since the end of 2009, a new route has appeared: Phnom Penh, Kuala Lumpur and Belgrade where the networks benefit from the logistical assistance of their embassy and of the city's Chinatown. This itinerary has been much used, with the Chinese not requiring visas for the Federal Republic of Yugoslavia due to the privileged economic relations between the two countries.

They then attain the Schengen area through countries of the former Soviet bloc, in particular via the Balkans route.

Since the beginning of 2010, it has been observed that Chinese illegals heading for the United Kingdom were increasingly using the services of couriers of other nationalities (Yugoslavs, Italians and Indians) organising grouped crossings of illegals in lorries. The vast majority of these road trips left the Netherlands, crossed Belgium and then arrived in the UK via

\footnotetext{
${ }^{2}$ Ioan Hurdubaie, Guest Interpol global crime threat, Bulletin of Information and Documentation of the Ministry of Administration and Interior no. 4/2011, p. 71-95
} 
Zeebrugge (Belgium) or via Calais. The discovery by British immigration officials in Dover, on 19 June 2011, of 58 Chinese illegals who had died of asphyxiation in a lorry registered in the Netherlands is a tragic illustration of this modus operandi.

Some illegals make long journeys by road via Eastern Europe (Russia, Czech Republic) to countries of the European Union, on board articulated lorries, sometimes even locked in containers.

Finally, Member States of the European Union have been informed, since 2007, of Belgrade role as hub for the Chinese networks having their destination Western Europe, after transiting various Central and Eastern European countries such as Hungary. Thus, a message sent out by Italy in August 2007, via the rapid alert system of the centre d'information, de réflexion et d'échanges en matière de franchissement des borders et d'immigration (CIREFI - Centre for information, thought and exchange of information concerning border crossings and immigration), alerted us to the presence of 40 to 50000 Chinese nationals in the Federal Republic of Yugoslavia who were liable to migrate to the Member States. Since the recent halt to Peking/Belgrade ${ }^{3}$ flights, the networks now use Moscow as hub to "springboard" into Western Europe.

By sea, there are mass departures of illegals (mainly from the province of Fujian) travelling in containers, from the coasts of Southern China, heading for Australia, Japan, and the USA.

Since the beginning of 2007, this sea transport has affected the Mediterranean zone: successive landings of illegals in Pouilles, with sea convoys apparently departing from Montenegro; transports of illegal immigrants in inflatable dinghies, departing from Ceuta and Melilla (Spanish territories in Morocco).

Through the various enquiries which have been undertaken, it now appears that the Chinese illegal immigration networks are generally directed from China with the assistance of structures established in the various European countries concerned.

The networks have many accomplices among their countrymen now established in the countries which are crossed. They provide their clients with falsified and forged passports, or passports stolen blank, of nationalities which are not subject to visa requirements for France or other destinations (Japanese, Korean, Singapore). These documents may also be obtained by obliging officials (authentic passports from Senegalese offices delivered to Chinese businessmen, Honduran passports obtained after naturalisation in return for investment in the national economy in the form of payment of a sum of US\$37,000 into an account opened with the Honduras central bank).

As it is difficult to obtain a visa pour France in Chins, the illegals pass via the diplomatic offices of Turkey or Italy but also of Eastern Europe (Poland, Bulgaria). Moreover, Belgian, Dutch and Austrian visas for the Schengen area which have been stolen blank are used by the networks as a last resort. Finally, the organisers have themselves sent letters of invitation from French companies for business trips as such documents near-systematically facilitate the issuance of visas in good form.

On the arrival of the illegal immigrants on to French territory, the passports are recovered by the network representative, and then returned to China by express courier service such as DHL, in order to recycle them. After being falsified once again, they are provided to new "clients" by the organisation.

These networks adapt very quickly and change their modus operandi as often as necessary. This, when it became difficult to obtain Schengen visas from the Greek consulate in Hong Kong, the new technique consisted in using authentic Chinese passports which had been falsified by changing the photograph, to which Schengen visas, stolen blank from various European consular offices (particularly Belgian, Austrian and Greek) ${ }^{4}$, were applied.

\footnotetext{
${ }^{3}$ Organized Crime Investigation - The Enterprise Investigative Approech, Federal Bureau of Investigation, Budapest, 2009, p. 15-199.

${ }^{4}$ Europol Convention.
} 


\section{F. Mateaş}

\section{3. - The Iraq/Kurd networks}

Illegal Iraqi immigration, which is very substantial in quantity, has the European Union as its final destination. It is motivated by political reasons (essentially connected to the Kurdish problem) and to economic ones.

Even though Germany, the Netherlands, the United Kingdom, and Scandinavia are target countries, France as a preferred transit country is faced with this problem to a substantial degree.

The modus operandi

In general, Iraqi illegal immigrants use the sea route from Istanbul to arrive in Greece and then Italy. Transit across France is made in light vehicles after crossing the Italian border.

Arrival by air is rare ( 89 non admissions at the Paris Roissy Charles de Gaulle Airport up to 20 July 2011, immediately followed by applications for political asylum).

Depending on the form of transport used, the illegals either have no documents or bear documents which are falsified by substitution of the photograph, often of Greek or Italian origin.

Iraqi immigration concerns people who generally hail from Kurdish ethnicity. It should not be forgotten that Syrians or Turks will claim that they are Kurdish in the hope of benefiting from political asylum.

This is also the case for Turkish or Syrian Kurds, as witnessed in the East Sea affair. The 910 refugees unanimously declared that they were from the region of Mossoul and were victims of the regime of Saddam Hussein. After enquiries, it turned out that only $25 \%$ were indeed from Iraq, but that the majority of them were from Syria.

The routes used

The illegals enter France via the land borders with Italy, Germany and Belgium, and arrive in the greater Paris area where the networks have lodgings. The presence of a Kurdish community which is properly and legally established in France allows the smugglers to find assistance (couriers and lodgers) among ideological sympathisers (essentially P.K.K.) or more prosaically from among those fellow countrymen who wish to make a substantial profit from this trade. Arrivals in Italy most often concerns Kurds who cannot legally be deported ${ }^{5}$.

In September 2011, a new itinerary was discovered to be used by Kurds from Northern Iraq. Groups of Kurds met in Iran, then crossed the regions controlled by the Taliban to arrive in Libya. From there, they managed to reach Greece and then Italy by boat. After crossing the Italian peninsula, they arrived in Switzerland in order to attain Germany.

Smugglers assist them by providing them with a complete set of western clothes as well as counterfeit or falsified Italian identity documents to present on control.

From Italy, the journey is made by train to Germany. In general, the smugglers supervise the illegal immigrants but travel in separate coaches. In the event of being questioned, the illegals present themselves as applicants for asylum from Kurdistan.

From Iraq, two itineraries have been detected:

1. Iraq $\Rightarrow$ Iran $\Rightarrow$ Turkey.

2. Iraq $\Rightarrow$ Syria $\Rightarrow$ Turkey.

In Turkey, a gathering of illegal immigrants, including both Iraqi Kurds and Turkish Kurds, is undertaken in Istanbul by the organisers. From there, the networks send the Kurdish illegals, whether of Iraqi or Turkish nationality, by normal or illicit sea route to Italy from the Turkish ports of Izmir and Canakkale.

The illegals then cross Italy by rail to reach the French border. They then travel up by all means of transport by one of two routes: 1. Vintimille-Calais (France) in order to reach the United Kingdom,

\footnotetext{
${ }^{5}$ Statement of Mr. James N. Purcell Jr., Director General of the International Organization for Migration.
} 
2. Vintimille-Strasbourg (France) in order to reach Germany.

In the Calais region, the network divides into two distinct branches: one carries Iraqi Kurds, and the other Turkish Kurds.

While the Turkish Kurd network use couriers recruited in Paris or in London from among penniless Europeans, the Iraqi Kurdish network only uses the services of their fellow countrymen.

1.4. The Pakistani networks

Pakistan is both a source country and transit country for the illegal immigration networks, which are always dominantly led by Pakistanis and whose purpose is to ensure the passage of Indians and Pakistanis to the European Union (in particular the United Kingdom) and Canada.

Modus operandi

The Pakistani networks are well structured and equipped with elaborate hosting logistics (notably including property for accommodation). Once in our territory, the illegals also benefit from support in drafting administrative applications for entry, residence or work permits. These are very active networks, but have developed little as regards their modus operandi and their destination. The United Kingdom is still the destination of preference, which will potentially allow them to go to Canada later.

Two great transit routes are to be distinguished:

1/ by the north: by air to Russia (Moscow, Saint Petersburg) or Ukraine (Kiev), then by train to Poland or the Czech Republic. Entry into the Schengen area is made to Germany by car;

2/ by the south: overland (mainly by lorry) to Turkey. From Turkey, the illegals reach Greece, by train or lorry or by sea to the Ionian Islands. Then, from the Greek ports of Patras or Igoumenitsa, they land on the Italian coast and travel up to other countries in the Schengen ${ }^{6}$ area.

The latest routes discovered are as follows:

Sea carriage: illegal immigrants are recruited by a travel agency in Karachi (Pakistan) which provides, at a cost, documents of convenience (sailor's pass and passport with consular visa). After a first leg by air to Cairo or Algiers, they then travel to a French port by boat. Once they arrive in France, they leave the ship after remitting their savings and their documents of convenience. According to a SCTIP unit in Karachi, these false sailors come from the mountain regions of Pakistan.

In January 2012, during an investigation undertaken by the PAF (Border Police) for Pyrénées-Orientales, a new itinerary was identified which transits via Tehran, Istanbul and Athens. This network, which also takes on illegal immigrants of other nationalities, apparently then uses the sea route to arrive at the Italian coast. Finally, the railway network allows them to reach Portugal via Milan, Paris, and Barcelona. The entire journey is billed at $€ 5000$ per illegal immigrant.

During 2012, the Pakistani immigration department investigated a large network which was working in combination with three travel agents in Karachi. This network ferried illegals by a two-legged air route to Europe:

- first of all as an Afghan, together with authentic passport, the illegal immigrant travelled to the United Arab Emirates using a non-European airline;

- then, under a Pakistani identity together with a Schengen visa which was either stolen or from a batch of documents signalled as having been stolen, the illegal immigrant would travel to Amsterdam by a KLM flight or London on British Airways. This itinerary is billed at approximately 100,000 francs (15,244.90 euros) per illegal immigrant.

\footnotetext{
${ }^{6}$ Standard regional anti-trafficking training for police in south-eastern Europe, Edited by ICMPD, Printed by the Austrian Federal Ministry of the Interior, p. 49-52
} 


\section{F. Mateaş}

The members of the organisations are specialists in the use of falsified administrative documents.

They may come from thefts, either in Pakistan (e.g. theft in Karachi, in March 2012, of 1200 Pakistani passports in the premises of the Pakistani administrative authorities) or in Europe (e.g. theft of a large number of administrative documents, passports, national identity cards, visas, and wet stamps, stolen in December 2011 from the premises of the Netherlands embassy in Luxembourg and signalled on 15 March 2012 by the Dutch police force).

The Pakistani networks therefore obtain supplies of stolen blank European documents and also benefit from the services of document forgery shops in Karachi and Islamabad.

Corruption is one of the characteristic aspects of Pakistani society: it is thus possible to obtain authentic European visas for the equivalent of 7,500 euros, obtained from dishonest consular services employees, through the travel agents.

The SCTIP units in Pakistan (Karachi and Islamabad) have reported numerous cases, since June 2009, of falsification of Schengen and British visas and issued by the consular services which are established in these two cities. These excellent forgeries are undetectable except with the use of expensive equipment which the services in charge of proceeding with checks at the borders rarely have.

Finally, over the last few years the French consulate in Islamabad and the PAF (Border Police) have observed that a number of family regoupment files were constituted on the basis of false payslips of false employment certificates from companies managed by Pakistanis or people of Pakistani origin residing in France. On examining these files, it appeared that a number of companies were fictitious or mere shells ${ }^{7}$.

\subsection{The Afghan networks}

Afghanistan is undoubtedly a source country for illegal immigration. Lacking access to the sea, this enclave is surrounded to the north by Turkmenistan, Uzbekistan and Tadjikistan; to the west by Iran; to the south-east by Pakistan; to the north-east by the autonomous region of Xinjiang in China.

Afghanistan is larger than France (an area of $652,090 \mathrm{~km} 2$ ). Its population, estimated at $24,792,375$ (census of 2008) is essentially agricultural, very dispersed and forms a complex ethnic mosaic, accentuated by the persistence of structures on a tribal basis and the permanence of clan organisations. Despite this great diversity, its peoples have their common points: the majority is poor and illiterate.

Since the Soviet invasion in 1979 , the country has experienced a veritable haemorrhage with the emigration of some 5 million people. Since that time, Afghanistan has always been at war, by 2014.

As a result, the flow of refugees from the country has only increased. Currently, the United Nations' High Commission for Refugees (H.C.R.) consider that Afghans constitute the largest group of refugees in the world.

Transiting via Pakistan and Iran, they use any and all means to attempt to reach Australia, Cambodia, Cuba or Iceland, and naturally all of the European countries. Among the European countries the United Kingdom, via Calais, is a preferred target as it offers attractive living conditions.

The prospect of a better life, legally inaccessible to most of them, is a determining factor in making them attempt illegal immigration. Illegals, who reach Calais, in order to cross to the United Kingdom, stay there the time necessary for their couriers to get them across the channel.

The smuggling networks gravitate around the Sangatte Red Cross centre, in Calais and in its neighbouring region. The local territorial forces of the border police, which have

\footnotetext{
${ }^{7}$ United Nations Protocol against the smuggling (illegal introduction) of migrants by land, sea and air, as an annex to the UN Convention against Transnational Organized Crime, 2010.
} 
jurisdiction on a local level, regularly bring proceedings against these particularly prosperous networks.

In addition, said centre has become a regular theatre for violent confrontations between Kurdish and Afghani illegal immigrants who make up the majority of the thousand or so people constituting the permanent population.

Finally, the reinforced controls put into place by the sea lines and by the Channel tunnel have not quelled the desire to reach the United Kingdom in the slightest, and has had the perverse effect of increasing the risks taken by the illegals.

On 2 August 2011, 150 Afghanis began a hunger strike in the Sangatte to draw the attention of the media and the UN to their plight.

\subsection{Update on Afghan illegal immigration}

Since September 2008, there has been strong growth in Afghan-origin illegal immigration. This has been noted through an increase in the number of people questioned in the département (county) of Nord-Pas-de-Calais.

According to various sources of information, two types of network leaving from Kabul and Karachi (Pakistan) have been brought to light, each with their own modus operandi and trajectory.

\section{Starting from Kabul}

This network takes on illegal immigrants in order to lead them to Moscow, by air or overland (generally in lorries). For this, they have Pakistani passports which are falsified by substitution of the photograph.

From the Russian capital, they are then transported by lorry, van or car to the Netherlands where the illegal immigrants are lodged and taken care of by the couriers.

From Amsterdam the couriers, often of Surinamese or Turkish nationality, have the illegals cross via Belgium in order to reach France and attempt to cross by ferry to the United Kingdom, via the port of Calais. For this they use hired utility vehicles in order to transport groups of ten to thirty people. After boarding the ferry, the courier leaves the vehicle while the illegals, lacking any identity documents, mingle with the passengers of the ship.

Once arrived in the United Kingdom, the illegal immigrants demand political asylum under Afghan nationality. It is particularly difficult to establish the identity and nationality of these illegal immigrants, as the British authorities come up against a virtually illiterate population. Most Afghans do not know their date of birth and all claim to be born in Kabul even when they come from rural provinces.

In order to add to the confusion, Pakistani nationals play on their physical similarities in order to pass themselves off as Afghanis, thus hoping to obtain political asylum more easily.

France remains a country of transit for these illegals. To date, no structured network has been identified in France. Those Afghani illegal immigrants who are questioned in France, mostly in Calais, are awaiting passage to the United Kingdom and most of them have come from the Netherlands.

- Leaving from Pakistan (Karachi)

Organised from Karachi in Pakistan, another route is used by Afghanis who take charge of the transport of their fellow countrymen. The modus operandi is more sophisticated and itinerary complex and effective.

The Afghani illegals first undertake the voyage Karachi-Dubai (United Arab Emirates) with an Afghan passport and a return ticket in order not to raise any suspicion during border control.

Once arrived in Dubai, they are contacted by smugglers who provide them with a Pakistani passport bearing a Schengen visa obtained from certain obliging European consular services. Under their new Pakistani identity, the illegals travel to Paris on a return ticket, again not to arouse suspicion. 


\section{F. Mateaş}

Once they have arrived in France, bearing a ticket for Paris-Karachi or Islamabad via London, the illegal immigrants continue their voyage and profit from the stopover in London to get rid of all identity documents and demand asylum under their Afghan identity, safe in the knowledge that they will not be deported back to their country.

\section{Nature of the migratory pressure}

2. 1. Analysis of the illegal migratory pressure on the borders of France in 2012

A global analysis of the indicators provided by DCPAF for the year 2012 reveals a fall of 5\% in illegal migratory pressure on the borders of France compared to 2011. 44,815 aliens were either "not admitted" or "re-admitted" towards third countries compared to 47,002 in 1999. 6. The largest flows come from Iraq $(+39.1 \%)$, Turkey $(+21.4 \%)$, Morocco $(-8.3 \%)$, Yugoslavia $(-65.9 \%)$, Iran $(+195.6 \%)$ and China $(-0.6 \%)$.

- The non-admission measures taken:

- mainly at the land borders: 30,950 compared to 36,322 (69\% compared to 77, 3\%);

- then the air borders: 12,540 compared to 8,962 (28\% compared to $19,1 \%)$;

- finally the sea borders: 889 compared to 1,228 (2\% compared to 2, 6\%).

2. 2. Analysis of the phenomenon for the first half of 2013

Despite that, the number of illegal aliens questioned by the Border Police increased substantially, going from 27,293 to 43,508 this year, i.e. a, increase of $59.4 \%$.

Finally, 10,832 aliens found bearing forged documents were also questioned by the Border Police in 2012 compared to 9,462 in 2011, i.e. an increase of $14.5 \%$.

\section{Conclusions}

An analysis of the indicators provided by DCPAF for the first half of 2013 reveals a global reduction of $21 \%$ in measures applied by it against aliens who did not fulfil the requirements for entry into France.

These flows mainly come from Iraq $(+2.8 \%)$, Morocco $(-33 \%)$, China $(-1.3 \%)$, Turkey $(-$ $41 \%)$, and Mali (+139\%).

On the other hand, the air borders, particularly concerned by this migratory pressure, did not record any fall (increase of $7 \%$ in placings in waiting zones).

For the land borders, for over a year now we have been witnessing a strong migratory movement starting in Italy and with the United Kingdom ${ }^{8}$ as destination.

For the first half of $2013,30,478$ aliens were questioned, of which 17,931 said they were Afghani and 8,842 Iraqi. If this trend were to continue, the annual total of persons questioned in 2013 could attain 60,000.

Concerning the sea borders, 1,250 illegals were questioned up to the 1 st half of 2013, i.e. an increase of $207 \%$ for the same reference period.

This trend may be mainly explained by the measures taken following the beaching of the cargo vessel "East Sea", on 17 February 2014.

\section{References:}

- Ion Suceava, Florian Coman, Crime and international organizations, ROMCARTEXIM Publishing, Bucharest, 2007.

- Ioan Hurdubaie, Guest Interpol global crime threat, Bulletin of Information and Documentation of the Ministry of Administration and Interior no. 4/2011.

- Organized Crime Investigation - The Enterprise Investigative Approech, Federal Bureau of Investigation, Budapest, 2009.

- Europol Convention

\footnotetext{
${ }^{8}$ United Nations Convention against Transnational Organized Crime, 2011.
} 
- Statement of Mr. James N. Purcell Jr., Director General of the International Organization for Migration.

- Standard regional anti-trafficking training for police in south-eastern Europe, Edited by ICMPD, Printed by the Austrian Federal Ministry of the Interior.

- United Nations Protocol against the smuggling (illegal introduction) of migrants by land, sea and air, as an annex to the UN Convention against Transnational Organized Crime, 2010

- United Nations Convention against Transnational Organized Crime, 2011 